between the two organizations by means of which the risks of new developments could be more accurately apportioned. If they were private companies the solution would be simple-one would buy a stake in the other. Is it entirely outrageous therefore to suggest that there should be some common membership between the Central Electricity Generating Board

\section{Prices for Drugs}

THE trade association for the British pharmaceutical industry has reacted vigorously to the publication last week of the Report of the Government Committee which has been studying the relationship between the pharmaceutical industry and the National Health Service (Cmnd 3410, HMSO, 17s. 6d.). The principal recommendations of the Sainsbury Committee are that there should be established an independent medicines commission with power to license the introduction of new drugs, to regulate their use, to help doctors decide which medicines should best be employed and to control advertising of drugs. The report also says that the Ministry of Health should be empowered to obtain from manufacturers detailed statements of the cost of individual drugs and that it should be able to determine prices paid for drugs supplied to the National Health Service on the basis of a reasonable return on the capital employed. In its reply to the report, the Association of the British Pharmaceutical Industry says that some of the recommendations of the Sainsbury Committee would "effectively amount to state control" of the industry. The association takes the line that the Sainsbury Committee may have been misled in arriving at its views on present pricing policies in the industry by the profits earned by a small number of companies.

However this dispute may be resolved, the Sainsbury Committee will have done a considerable service by providing a detailed picture of the state of the British pharmaceutical industry. The total output of the industry amounts to roughly $£ 250$ million a year, and between 55 and 68 companies account for more than 95 per cent of the total value of materials supplied to the National Health Service. Of the medicines supplied on prescriptions in 1966, 27 per cent came from British companies, nearly a half (by value) from companies controlled from the United States and the rest from companies controlled from the mainland of Europe. Exports run at about $£ 30$ million a year net. The value of drugs supplied to the National Health Service has risen over the years, largely because of the increasing proportion of proprietary medicines now used in the National Health Service, from $£ 43 \cdot 6$ million in 1949 to $£ 173.5$ million in 1965 . The views of the Sainsbury Committee on drug prices are based on an analysis of the profitability of 27 important companies each selling more than $£ 1$ million worth of drugs to the National Health Service each year. Seventeen of these companies earn profits of more than 20 per cent of the capital employed and 8 of these had rates of profit exceeding 30 per cent. Not all companies, however, were equally prosperous. Four of them earned profits in the three years 1963-65 which work out at less than 10 per cent of their capital employed. In its comment on these figures, the committee suggests that drugs supplied to the National Health Service in the early sixties may have been priced excessively "to the extent and the Atomic Energy Authority? In the long run that would be an effective means of making sure that new reactor developments were likely to find a ready customer. In the immediate future it would help to ensure that the present unnecessary, let alone wasteful, duplication of research laboratories by the two organizations could be somehow done away with.

of several million pounds". It rejects the view that high profitability is necessary if companies are to be encouraged to undertake research on a sufficient scale by saying that "firms which have sustained a research programme involving a substantial number of research personnel have emerged with encouraging regularity with products which have remained dominant in their field of therapy for a considerable time".

In the industry as a whole, the amount spent on research directly related to National Health Service products in 1965 was $£ 16$ million, or $9 \cdot 7$ per cent of the total sales of National Health Service drugs. Altogether, fundamental research aimed at the production of entirely new products seems to have accounted for between 56 and 58 per cent of the total research bill. By comparison, process development took much smaller sums of money-13.5 per cent. Because of the way in which many of the companies which operate in Britain make use of research carried out elsewhere, it appears that more than $\mathfrak{f 3}$ million each year should be added to the value of the work done in British laboratories. The Sainsbury Committee suggests that some of the work classified by companies as fundamental research may not always deserve that name, but nevertheless considers that the figures available do not support assertions that the industry neglects long-term work. The committee does, however, consider that there could be closer links between the companies and the universities. All this implies that the pattern of research in the British pharmaceutical industry is unlikely to be seriously disturbed by the appearance of the Sainsbury report.

\section{Double or Nothing}

THe launching of a new communications satellite over the Pacific last week should make the advocates of a fifth transatlantic telephone cable rush to put in a good word for cables. But what is it ? Reliability, perhaps, or longevity or familiarity; the same arguments would do for the horse. The fact is that new cables can only add to existing capacity, while satellites can almost multiply it. Cables allow only pointto-point communication; satellites can allow many to talk at once. Even from a political point of view, they are more forward looking. Telephone calls from one underdeveloped country to another usually have to be routed through one of the old centres of powerNew York, London, Tokyo or Paris. But with satellites, just as distance means nothing (once it is 22,300 miles up), neither do national or natural boundaries.

Much has been made by those who hanker after cables-among whom are included the conventional communications carriers in the most articulate countries-of the failure of the first INTELSAT II satellite to achieve its proper orbit last autumn. But even that 
functioned for about eight hours a day and its successor a few months later made available, all around the clock, all types of telecommunications between the Pacific Coast of the United States and the Far East. The Pacific satellites have done something more: brought down cable rates. The trans-Pacific charges set by Comsat, the United States Communications Satellite Corporation, were so much lower than those set by the cable carriers that the Federal Communications Commission ordered these to cut their prices or let Comsat take over their business with the American defence department. This is why the American Telephone and Telegraph Company is now preparing another cut in trans-Atlantic rates, presumably to match the satellite competition.

The economics of satellites are uncertain. The first sent over the Pacific was, in a sense, a waste of money (although a failure rate of one in five launchings has been budgeted for). It is no longer in use. But Early Bird has been working a full year longer than expected on the Atlantic run; estimates for the lifetime of satellites have been deliberately pessimistic. The chances that they will be cheaper than anyone thought are probably better than that they will be more expensive.

The recent launch put the fourth INTELSAT II into the sky. (One is over the mid-Atlantic, where it can make up for the inability of Early Bird to provide links with the southern hemisphere as well as simultaneous television and telephone transmission.) The newest has been sent into synchronous equatorial orbit over the Pacific at approximately 175 degrees East. All are about twice the weight of Early Bird, weigh about 192 pounds and are 56 inches in diameter and 26.5 inches high, not counting antennae. Next year, however, the stout string and sealing wax stage should be over for good.

The INTELSAT III series of satellites should by then have been launched, all six of them. Built by TRW Incorporated for a basic price of $\$ 32$ million, these will have three times the capacity of the INTELSAT II satellites and should ensure continuous operation, even if one or even two go dead. By 1969, moreover, the total number of ground stations around the globe is expected to be 40 -including one in Spain, which is also being mentioned as a possible terminus for the new telephone cable.

\section{Victory on Pensions}

The Institution of Professional Civil Servants seems to have won a tangible if modest victory in its dealings with the Department of Education and Science on behalf of scientists working for the research councils who may find themselves being transferred to the British Civil Service. The issue is the ease with which people moving into or out of the Civil Service can retain their pension rights in full. Hitherto transfers of this kind, an increasingly common hazard now that public laboratories of all kinds are beginning to respond to the public clamour for mobility, have been governed by the rule that entitlement to pension is within the discretion of the Civil Service. Although the research councils and the Civil Service operate pensions schemes which are closely similar, and which are in particular non-contributory, it has been possible for the Civil Service to take an awkward line in its dealings with transfers. Sometimes, for example, the question has been raised of whether people leaving a Civil Service laboratory for a job with one of the research councils have had no assurance that the full value of their pensions rights would be transferred. What seems now to have happened is that the Institution of Professional Civil Servants has won the agreement of Mr Patrick Gordon-Walker, Secretary of State at the Department of Education and Science, that transferability would in future be automatic for movements between the Civil Service and the research councils. Transferability between the Civil Service and the research councils on the one hand and the rest of the world on the other continues to be impeded by lack of transfer rights, although it is hard to see how the Fulton Commission on the Civil Service can fail to recommend the abolition of this anomaly.

News of the dispute between the Institution of Professional Civil Servants and the Science Research Council about the pensions rights of those employed at the Daresbury Laboratory is less cheerful. A writ against the council by the institution is due to be heard in the courts later this year. The issue is exceedingly complicated, chiefly because of the reorganization of government science under the Science and Technology Act of 1965. The act was the legal instrument which established the Science Research Council and which transferred to it the activities of the National Institute for Research in Nuclear Science, then the operator of the Rutherford Laboratory at Harwell and the body responsible for building the Daresbury Laboratory. Because the Rutherford Laboratory had grown out of the Atomic Energy Authority's laboratory at Harwell, it had been agreed that employees at the Rutherford Laboratory should retain, if they chose, membership of the contributory pensions scheme operated by the AEA. The need to perpetuate this arrangement under the new legislation was apparently recognized only at a late stage of the passage of the bill through Parliament, and an amending clause was introduced in February 1955. This clause laid down that the right to opt for AEA pensions should apply not merely to those already "employed by the National Institute for Research in Nuclear Science" but also to those subsequently taken on "to work on activities taken over . . . from the National Institute for Research in Nuclear Science", but Lord Snow told the House of Lords at the time that there was no intention that this provision should apply to Daresbury as well as the Rutherford Laboratory. The Institution of Professional Civil Servants has taken issue with the British Government's view that the Act will permit such an interpretation. Whatever the courts decide, it is hard to think that these arrangements will survive the acid test of feasibility, let alone the report of the Fulton Commission now only half a year away.

\section{Aldabra Expedition Returns}

The first phase of the Royal Society expedition to Aldabra, the atoll in the Indian Ocean where the Ministry of Defence proposes to build an air staging post and the $\mathrm{BBC}$ would like a transmitter, is now complete. Seven scientists have returned after spending five weeks on the atoll, making preliminary inves. tigations of numbers and distribution of animals and plants, both on the atoll and in the lagoon. They have come back convinced that Aldabra should be preserved, 